\title{
RANCANG BANGUN EQUALIZER TEGANGAN SEL MENGGUNAKAN FLYBACK KONVERTER UNTUK BATERAI LI-ION TERHUBUNG SERI
}

\author{
Tegar Subekti, Heri Suryoatmojo, dan Sjamsjul Anam \\ Jurusan Teknik Elektro, Fakultas Teknik Industri, Institut Teknologi Sepuluh Nopember (ITS) \\ Jl. Arief Rahman Hakim, Surabaya 60111 Indonesia \\ E-mail: tegar.subekti14@mhs.ee.its.ac.id ; suryomgt@ee.its.ac.id ; anam@ee.its.ac.id
}

\begin{abstract}
Abstrak-Saat ini, penyimpanan energi berbasis baterai memiliki peranan penting di berbagai sistem kelistrikan, mulai dari perangkat elektronik sampai dengan sistem berskala besar, termasuk mobil listrik. Baterai Lithium Ion saat ini menjadi paling unggul diantara teknologi baterai yang lain karena kepadatan energinya yang besar. Pada umumnya, sel tegangan dihubungkan seri dalam bentuk string untuk mencapai tegangan sistem yang dibutuhkan.

Sel Lithium Ion yang terhubung seri memberikan masalah teknis berupa ketidakseimbangan tegangan yang ada diantara sel yang terjadi karena performa setiap sel yang unik. Hal tersebut akan mengurangi kapasitas yang tersedia pada baterai sehingga lama waktu operasi akan berkurang dan mengakibatkan percepatan degradasi sel karena overcharge atau overdishcharge.

Equalizer tegangan sel menggunakan flyback konverter menggunakan arsitektur cell-to-string, dimana energi pada sel yang memiliki tegangan lebih tinggi akan ditransfer ke string untuk menyeimbangkan tegangan sel.
\end{abstract} Li-Ion

Kata Kunci - equalizer tegangan sel, flyback converter, baterai

\section{PENDAHULUAN}

$\mathrm{P}$ ENYIMPANAN energi berbasis baterai saat ini memiliki peranan penting di berbagai sistem kelistrikan, dari perangkat elektronik sampai dengan sistem berskala besar, termasuk mobil listrik. Baterai Li-Ion saat ini menjadi paling unggul diantara teknologi baterai yang lain karena kepadatan energinya yang besar, tingkat peluahan sendiri yang rendah (self discharge rate), dan tidak ada efek memori. Pada kendaraan hibrid (HEV) atau plug-in hybrid electric vehicle (PHEV) beterai Li-Ion disusun secara paralel dan seri untuk mencapai energi dan daya yang dibutuhkan HEV atau PHEV tersebut.

Sel Li-Ion yang terkoneksi seri memberikan masalah teknis berupa ketidakseimbangan tegangan yang ada pada antara sel yang terjadi karena inkonsistensi saat proses manufaktur dan performa yang unik pada setiap sel. Setelah baterai mengalami banyak siklus pengisian dan pengosongan, ketidakseimbangan ini akan terus bertambah. Hal tersebut tentu akan mengurangi kapasitas yang tersedia pada baterai sehingga lama waktu operasi berkurang dan dapat mengakibatkan percepatan degradasi sel dan bahaya seperti ledakan atau terbakarnya baterai karena overcharge atau overdischarge pada sel. Untuk itu, penyeimbangan untuk sel baterai yang terkoneksi seri dibutuhkan untuk mencegah fenomena tersebut dan untuk memperpanjang kerja baterai. Sebagai salah satu kunci dalam teknologi sistem manajemen baterai, equalizer tegangan sel mempunyai peranan penting di dalamnya.

Teknik penyeimbangan tegangan sel yang telah ada dapat dibagi menjadi 3 kategori, yaitu transfer energi secara resistif, transfer energi secara kapasitif, dan transfer energi dengan konverterelektronik.[1] Solusi dengan menggunakan flyback konverter masuk ke kategori transfer energi dengan konverter elektronik. Topologi ini tidak menggunakan penambahan charger dalam proses menyeimbangkan tegangan sel. Topologi ini dalam rangkaiannya diharapkan memiliki jumlah komponen pasif yang lebih sedikit dibandingkan dengan solusi konvensional.[2]

\section{URAIAN PENELITIAN}

\section{A. Prinsip Kerja Equalizer Menggunakan Flyback Konverter}

Proses ekualisasi pada topologi ini, lama waktu ekualisasi yang dibutuhkan akan bertambah secara linier sesuai dengan banyaknya jumlah sel dan besarnya perbedaan tegangan yang tegangan yang terdapat tiap sel[2].Untuk menjelaskan prinsip kerja equalizer maka $\mathrm{C}_{1}$ diibaratkan memiliki tegangan terkecil, $\mathrm{C}_{2}$ dengan tegangan terkecil kedua, $\mathrm{C}_{3}$ dengan tegangan terbesar kedua, dan $\mathrm{C}_{4}$ dengan tegangan terbesar $\left(\mathrm{C}_{1}<\mathrm{C}_{2}<\mathrm{C}_{3}<\mathrm{C}_{4}\right)$. Perbedaan tegangan antara $\mathrm{C}_{1}$ dan $\mathrm{C}_{2}$ lebih dari 0,02 Volt dan perbedaan tegangan $\mathrm{C}_{2}$ dan $\mathrm{C}_{3}$ lebih dari 0,02 Volt. Sehingga dalam keadaan tersebut proses ekualisasi terbagi menjadi 3 mode.

a) Mode Pertama

MOSFET pada sel dengan tegangan terkecil OFF selama mode pertama. MOSFET pada sakelar lain beroperasi berdasarkan urutan tegangan $\left(\mathrm{C}_{2} \rightarrow \mathrm{C}_{3} \rightarrow \mathrm{C}_{4}\right)$. Gambar 2 menunjukkan bentuk gelombang pensakelaran saat mode 1 ekualisasi. 


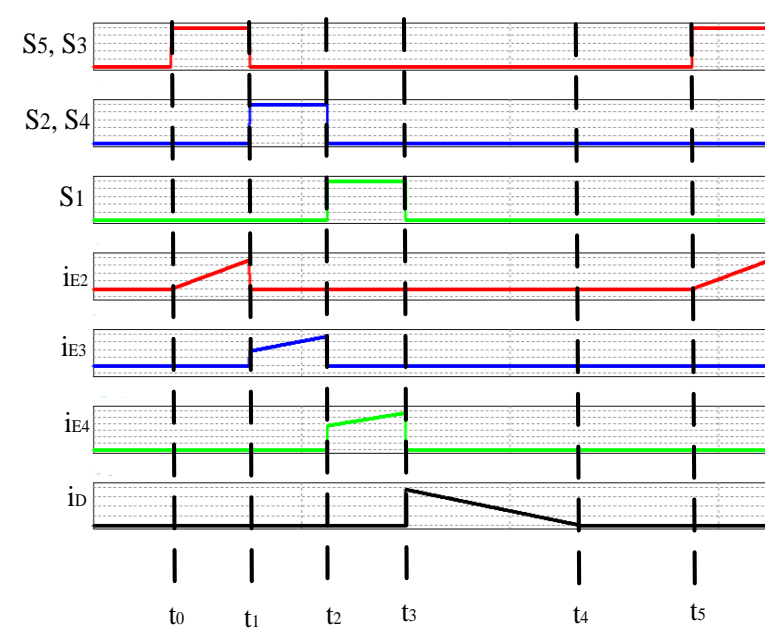

Gambar 2.Bentuk gelombang pensakelaran mode 1 ekualisasi

Saat interval $\left(\mathrm{t}_{0}-\mathrm{t}_{1}\right): \mathrm{S}_{5}$ dan $\mathrm{S}_{3} \mathrm{ON}$ berdasarkan urutan tegangan. Arus induktor $\left(\mathrm{i}_{\mathrm{Lm}}\right)$ bertambah yang semula bernilai nol. Arus discharge maksimal dari sel $\mathrm{C}_{2}$ ditunjukkan oleh persamaan (1).

$\hat{I}_{2}=\frac{V_{2}}{L_{m}}\left(t_{1}-t_{0}\right)$

Saat interval $\left(\mathrm{t}_{1}-\mathrm{t}_{2}\right): \mathrm{S}_{2}$ dan $\mathrm{S}_{4}$ ON berdasarkan urutan tegangan, arus puncakdischarge dari sel $\mathrm{C}_{3}$ adalah

$\hat{I}_{3}=\hat{I}_{2}+\frac{V_{3}}{L_{m}}\left(t_{2}-t_{1}\right)$

Saat interval $\left(\mathrm{t}_{2}-\mathrm{t}_{3}\right): \mathrm{S}_{1} \mathrm{ON}$ dan arus puncak discharge dari sel $\mathrm{C}_{4}$ adalah

$\hat{I}_{4}=\hat{I}_{3}+\frac{V_{4}}{L_{m}}\left(t_{3}-t_{2}\right)$

Jika

$\left(\mathrm{t}_{0}-\mathrm{t}_{1}\right)=\left(\mathrm{t}_{1}-\mathrm{t}_{2}\right)=\left(\mathrm{t}_{2}-\mathrm{t}_{3}\right)=\frac{d T s}{3}$

Maka flyback konverter berbagi waktu konduksi yang sama diantara 3 sel pada mode pertama, dan arus puncak induktor ditunjukkan oleh persamaan (5) dan arus rata-rata induktor ditunjukkan oleh persamaan (6)

$\hat{I}_{L m}=\frac{\left(V_{2}+V_{3}+V_{4}\right) d T_{S}}{3 L_{m}}$

$I_{\text {average }}=\frac{1}{2} \frac{\left(V_{2}+V_{3}+V_{4}\right) d^{2} T_{S}}{3 L_{m}}$

Saat interval $\left(\mathrm{t}_{3}-\mathrm{t}_{4}\right)$ tidak ada sakelar $\mathrm{ON}$, arus $\mathrm{L}_{\mathrm{m}}$ tidak dapat berubah seketika. Arus $i_{L m}$ masuk melalui bagian yang tidak bertanda dot (titik) dan keluar pada bagian yang tidak bertanda dot (titik) pada sisi sekunder[3], ilustrasi interval ini ditunjukkan oleh Gambar 3(b).

Saat interval $\left(\mathrm{t}_{4}-\mathrm{t}_{5}\right)$ tegangan induktor dan arus induktor adalah nol. hal ini menunjukkan bahwa konverter bekerja pada mode DCM.Gambar 3(a) menjunjukkan diagram rangkaian saat interval $\mathrm{t}_{0}$ sampai dengan $\mathrm{t}_{5}$.

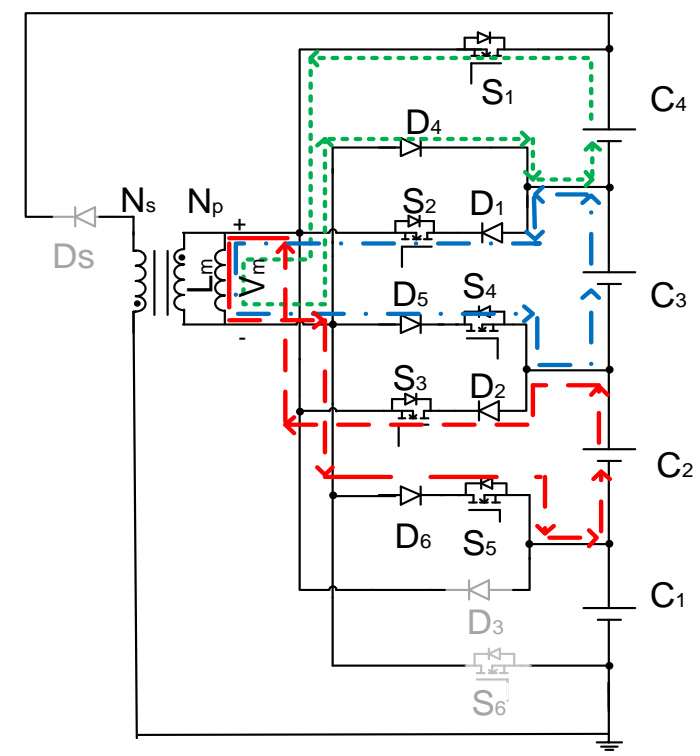

Gambar 3. (a) Diagram rangkaian untuk $\mathrm{t}_{0}-\mathrm{t}_{3}$

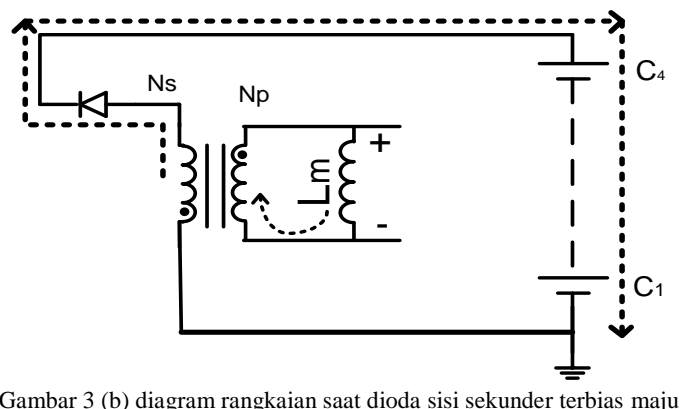

Proses ini terus berulang hingga tegangan salah satu baterai yang memiliki tegangan yang lebih tinggi ( sel $\mathrm{C}_{2}$ atau $\mathrm{C}_{3}$ atau $\mathrm{C}_{4}$ ) turun dengan nilai $<=0,02 \mathrm{Volt}$ dari tegangan terendah. Dalam penjelasan ini mengasumsikan tegangan $C_{1}$ dan $C_{2}$ adalah sama.

\section{b) Mode Kedua}

Mode kedua mikrokontroler menentukan kembali urutan pensakelaran. $\mathrm{S}_{2}, \mathrm{~S}_{4}$, dan $\mathrm{S}_{1}$ ON berdasarkan urutan tegangan $\left(\mathrm{V}_{3}<\mathrm{V}_{4}\right)$. Bentuk gelombang pensakelaran pada mode dua ditunjukkan oleh Gambar 4.

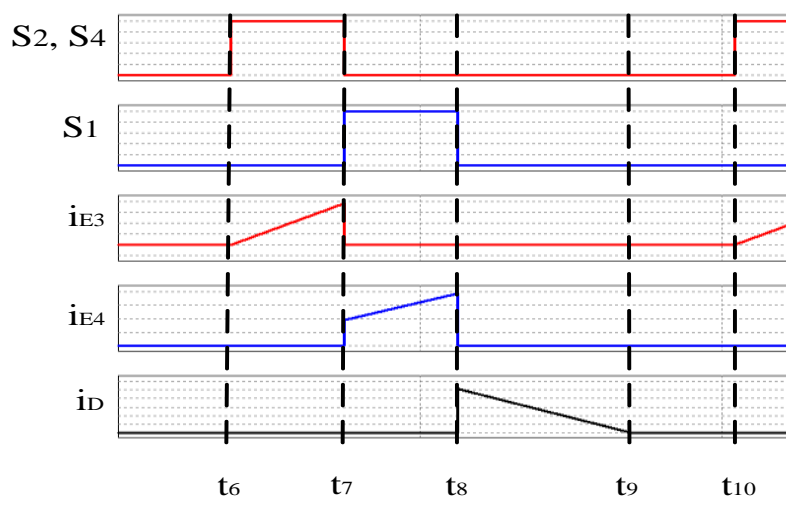

Gambar 4. Bentuk gelombang pensakelaran mode 2 ekualisasi 
JURNAL TEKNIK ITS Vol. 5, No. 2, (2016) ISSN: 2337-3539 (2301-9271 Print)

Saat interval $\left(\mathrm{t}_{6}-\mathrm{t}_{7}\right) \quad \mathrm{S}_{2}$ dan $\mathrm{S}_{4}$ ON berdasarkan urutan tegangan. Arus puncak discharge dari sel $\mathrm{C}_{3}$ adalah:

$\hat{I}_{3}=\frac{V_{3}}{L_{m}}\left(t_{7}-t_{6}\right)$

Saat interval $\left(\mathrm{t}_{7}-\mathrm{t}_{8}\right)$ S1 ON dan arus puncak discharge dari sel $\mathrm{C}_{4}$ adalah

$\hat{I}_{4}=\hat{I}_{1}+\frac{V_{4}}{L_{m}}\left(t_{8}-t_{7}\right)$

Disini besarnya

$\left(t_{7}-t_{6}\right)=\left(t_{8}-t_{7}\right)=\frac{d T s}{2}$

Karena flybackkonverter membagi waktu konduksi yang sama antara $\mathrm{C}_{3}$ dan $\mathrm{C}_{4}$, sehingga besarnya arus puncak induktor adalah:

$\hat{I}_{m}=\frac{\left(V_{3}+V_{4}\right) d T_{S}}{2 L_{m}}$

$I_{\text {average }}=\frac{1}{2} \frac{\left(V_{3}+V_{4}\right) d^{2} T_{S}}{2 L_{m}}$

Saat interval $\left(\mathrm{t}_{8}-\mathrm{t}_{9}\right)$ Saat interval ini tidak ada sakelar ON, dioda sisi sekunder terkonduksi, dan arus charging mengalir menuju baterai.

Proses ini terus berlangsung hingga salah satu tegangan dari sel $\mathrm{C}_{3}$ atau $\mathrm{C}_{4}$ turun ke level yang sama dengan sel yang memiliki tegangan yang lebih kecil $\left(\mathrm{C}_{2}\right.$ atau $\left.\mathrm{C}_{1}\right)$. Dimisalkan tegangan sel $\mathrm{C}_{3}$ turun ke level yang sama dengan $\mathrm{C}_{2}$.

c) Mode Ketiga

Pada Mode ketiga sel $\mathrm{C}_{4}$ di discharge, bentuk gelombang pensakelaran mode ke tiga ditunjukkan oleh Gambar 5

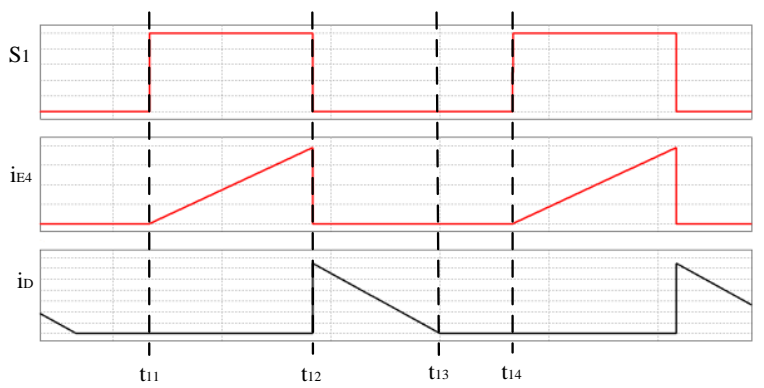

Gambar 5. Gelombang pensakelaran saat tahap 3 ekualisasi

Pada interval $\left(\mathrm{t}_{11}-\mathrm{t}_{12}\right) \mathrm{S} 1 \mathrm{ON}$, arus discharge maksimum dari sel $\mathrm{C}_{4}$ ditunjukkan dengan persamaan (12), dan arus discharge rata-rata ditunjukkan oleh persamaan (13)

$\hat{I}_{4}=\frac{V_{4}}{L_{m}}\left(t_{12}-t_{11}\right)$

$I_{\text {average }}=\frac{1}{2} \frac{V_{4} d^{2} T_{S}}{2 L_{m}}$

Saat interval (t12-t13) Saat interval ini sakelar OFF, dioda sisi sekunder terkonduksi, dan arus charging mengalir menuju baterai.
Proses terus berlangsung hingga tegangan $\mathrm{C}_{4}$ turun hingga sama seperti ketiga sel lainnya. Saat keempat tegangan baterai pada level yang sama atau memiliki perbedaan sebesar 0,01 Volt proses ekualisasi berakhir.

Beberapa mode dapat terulang beberapa kali pada tengah atau akhir proses ekualisasi berlangsung. Setelah proses ekualisasi berakhir, mikrokontroler tetap membaca tegangan masing-masing sel, jika ketidakseimbangan terjadi kembali maka proses ekualisasi dapat dimulai kembali.

\section{PERANCANGAN DAN IMPLEMENTASI EQUALIZER MENGGUNAKAN FLYBACK KONVERTER}

\section{A. Perancangan Flyback Transformer}

Adapun parameter-parameter perancangan flyback transformer yang telah ditentukan untuk digunakan dalam equalizer, antara lain:

1. Tegangan baterai maksimum :4,2 Volt/sel

2. Arus puncak discharge : kurang dari 2,5 A.

3. Frekuensi kerja mode $1: 20 \mathrm{kHz}$

4. Frekuensi kerja mode $2: 30 \mathrm{kHz}$

5. Frekuensi kerja mode $3 \quad: 60 \mathrm{kHz}$

6. Duty cycle mode 1, 2, dan3 : 0,45

7. Rasio primer dan sekunder $\quad: 1: 3$

a. Nilai Induktansi Magnetisasi

Berdasarkan persamaan (5) besarnya induktansi magnetisasi minimum yang dibutuhkan adalah sebesar:

$$
L_{m}=\frac{\left(3 . V_{\text {baterai }}\right) d T_{s}}{3 \hat{I}_{m}}
$$

Dimana :

$\mathrm{L}_{\mathrm{m}} \quad$ : induktansi magnetisasi $(\mathrm{H})$

$\mathrm{V}_{\text {baterai }} \quad$ : tegangan baterai $(\mathrm{V})$

d : :duty cycle

$\mathrm{T}_{\mathrm{s}} \quad$ :periode (s)

$\hat{I}_{m} \quad$ :arus puncak maksimum (A)

Perhitungan:

$$
L_{m}=\frac{(3 \cdot 4,2) \cdot 0,45 \cdot 5 \times 10^{-5}}{3.2,5} \geq 37,8 \mu \mathrm{H}
$$

b. Implementasi Flyback transformer

Nilai induktansi magnetisasi tidak dapat terukur secara langsung, dan didapat dengan cara mengetahui parameterparameter seperti induktansi sisi primer, induktansi sisi sekunder dan kebocoran induktansi primer.

Parameter induktansi sisi primer dan sekunder diperoleh dengan melakukan pengujian hubung buka pada sisi primer dan sekunder menggunakan LCR meter. Sedangkan kebocoran induktansi sisi primer dengan melakukan menghubung singkat sisi sekunder transformer[4].Bahan inti yang digunakan dalam implementasi flyback konverter adalah ferrite Berikut ini adalah parameter implementasi hasil pembuatan flyback transformer.

$$
\begin{array}{ll}
\mathrm{L}_{11} & =46,77 \mu \mathrm{H} \\
\mathrm{L}_{22} & =386,7 \mu \mathrm{H} \\
\mathrm{L}_{\text {lkg12 }} & =0,893 \mu \mathrm{H}
\end{array}
$$


JURNAL TEKNIK ITS Vol. 5, No. 2, (2016) ISSN: 2337-3539 (2301-9271 Print)

$$
\mathrm{L}_{\mathrm{lkg} 21}=5,319 \mu \mathrm{H}
$$

Dimana:

$$
\begin{array}{ll}
\mathrm{L}_{11} & \text { : induktansi sisi primer }(\mathrm{H}) \\
\mathrm{L}_{22} & \text { : induktansi sisi sekunder }(\mathrm{H}) \\
\mathrm{L}_{\mathrm{kg} 12} & \text { : induktansi bocor sisi primer }(\mathrm{H}) \\
\mathrm{L}_{\mathrm{kgg} 21} & \text { :induktansi bocor sisi sekunder }(\mathrm{H})
\end{array}
$$

Dari parameter-parameter tersebut, nilai induktansi magnetisasi diketahui dengan persamaan (15)

$$
L_{m}=\left(\frac{N_{1}}{N_{2}}\right) \sqrt{L_{11} L_{22}-L_{l k g 12} L_{22}}
$$

Sehingga besarnya induktansi magnetisasi sebesar

$$
L_{m}=\left(\frac{1}{3}\right) \sqrt{46,77.386,7-0,893.386,7}=44,4 \mu \mathrm{H}
$$

\section{B. Simulasi Equalizer Flyback Konverter}

Nilai $\mathrm{L}_{\mathrm{m}}$ yang akan digunakan disimulasikan untuk mengetahui proses ekualisasi yang nantinya dilakukan oleh konverter pada tahap implementasi. Parameter yang telah ditentukan dan dihitung dimasukkan ke dalam parameter simulasi. Gambar 7 menunjukkan rangkaian simulasi equalizer menggunakan flyback konverter.

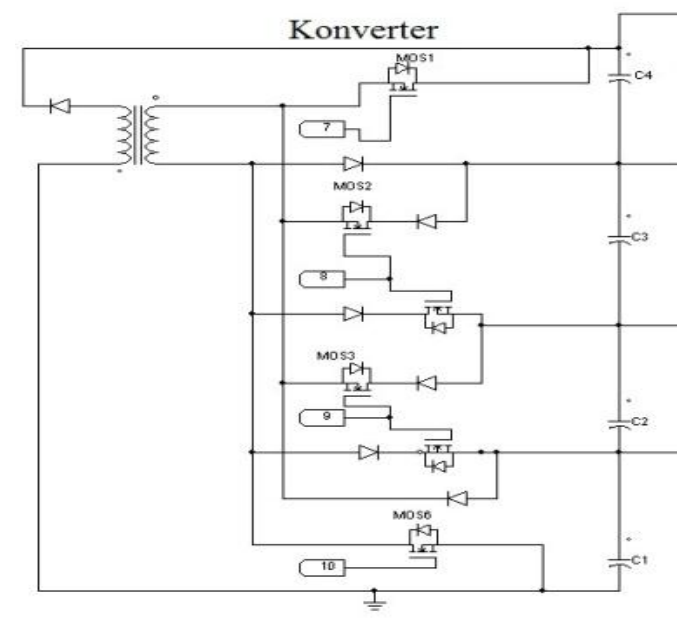

Gambar 7. Rangkaian Simulasi

Dalam simulasi nilai tegangan untuk masing-masing sel adalah: $\mathrm{C}_{1}=3,9, \mathrm{C}_{2}=4, \mathrm{C}_{3}=3,74$, dan $\mathrm{C}_{4}=3,79$. Dalam simulasi ini sakelar $\mathrm{ON}$ sesuai urutan tegangan.

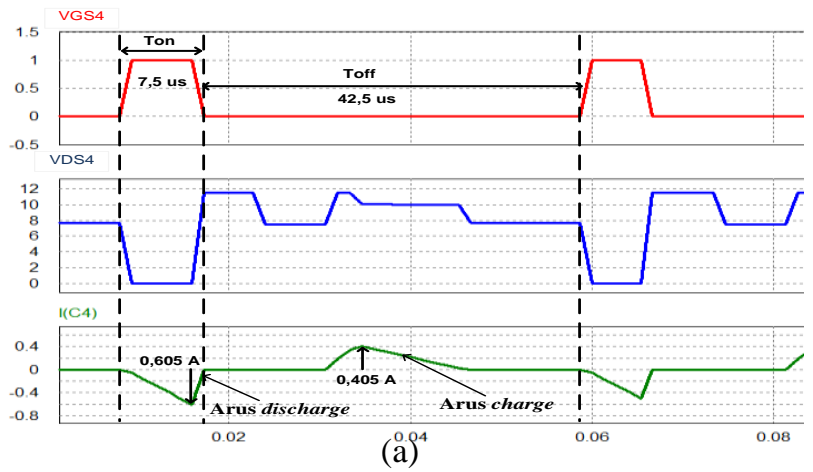

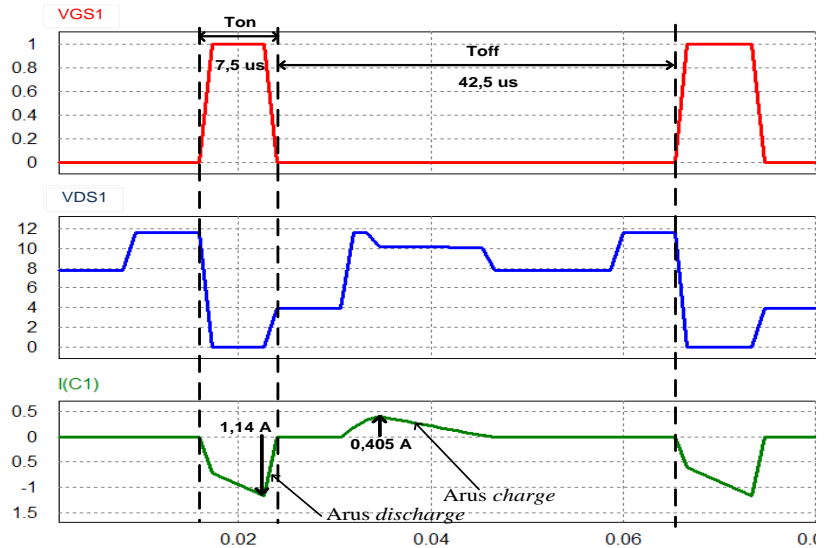

(b)

Gambar 8 Gelombang pensakelaran dan arus (a) $\mathrm{C}_{4}$; (b) $\mathrm{C}_{1}$

Nilai arus discharge pada urutan pensakelaran 2 dan 3 lebih besar karena sebelum $\mathrm{L}_{\mathrm{m}}$ discharge dan dioda sekunder konduksi, sakelar urutan selanjutnya ON, sehingga arus discharge akan semakin tinggi. Gambar 8 (a) dan (b) menunjukkan urutan pensakelaran 1 dan 2 sedangkan Gambar 9 (a) dan (b) merupakan gelombang pensakelaran 3 dan tegangan dan arus dioda sekunder.
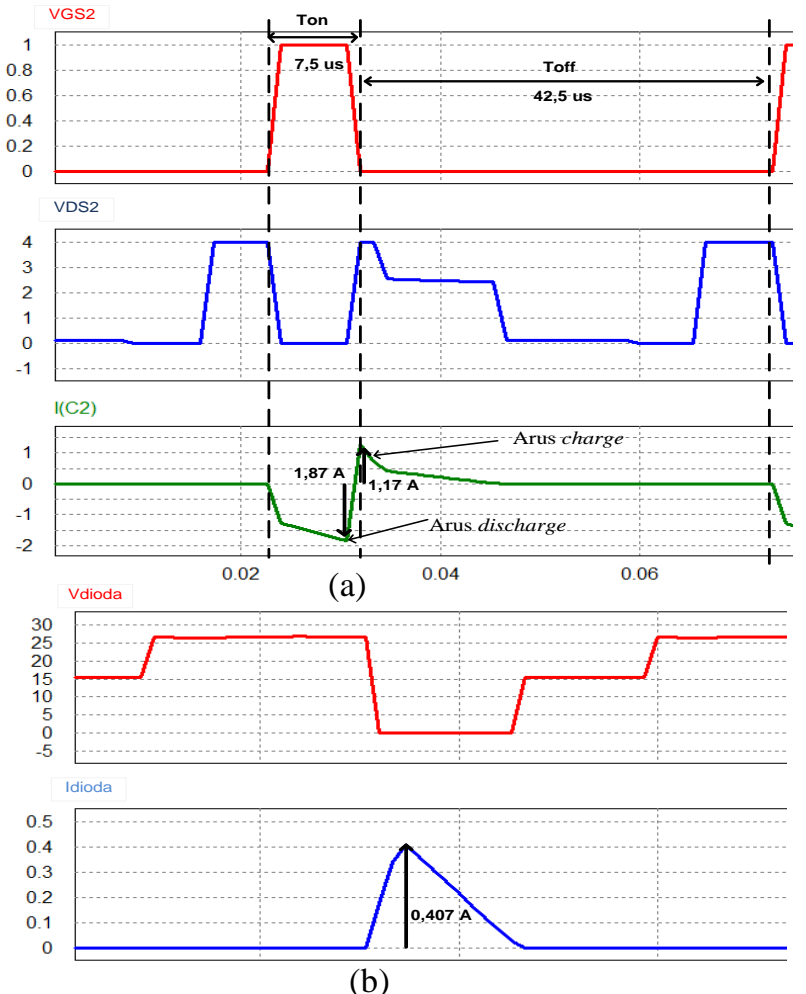

Gambar 9. Gelombang Pensdakelaran dan arus (a) $\mathrm{C}_{2}$ (b) Dioda sekunder

\section{Implementasi}

Komponen-komponen yang digunakan pada implementasi equalizer ini ditunjukkan pada Tabel 1 dan hasil implementasi berupa equalizer ditunjukkan oleh Gambar 11.

Tabel 1 Daftar Komponen Implementasi
Komponen
Nilai 
JURNAL TEKNIK ITS Vol. 5, No. 2, (2016) ISSN: 2337-3539 (2301-9271 Print)

\begin{tabular}{cc}
\hline Flyback Transformer & $44,4 \mu \mathrm{H}$ \\
Dioda & $1 \mathrm{~N} 5822$ \\
Sakelar MOSFET & IRF540 \\
Optocoupler & TLP250 \\
Mikrokontroler & ATMega 2560, Arduino Mega \\
\hline \hline
\end{tabular}

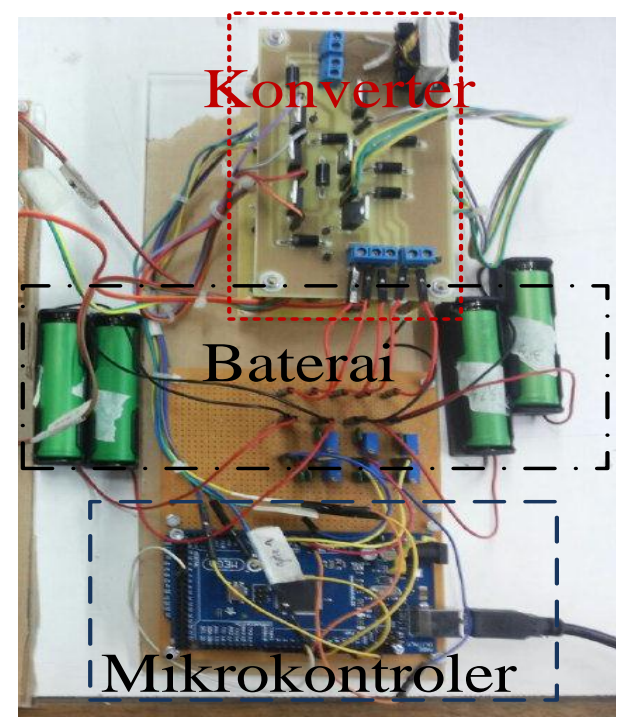

Gambar 10. Hasil Implementasi

\section{PENGUJIAN EQUALIZER}

\section{A. Pengujian Bentuk Gelombang}

Pengujian terhadap bentuk gelombang bertujuan untuk mengetahui kesesuaian kinerja konverter dengan perancangan dan simulasi. Gambar 11 menunjukkan bentuk gelombang PWM mode 1 dengan urutan pensakelaran $\mathrm{C}_{4}, \mathrm{C}_{1}$ dan $\mathrm{C}_{2}$.

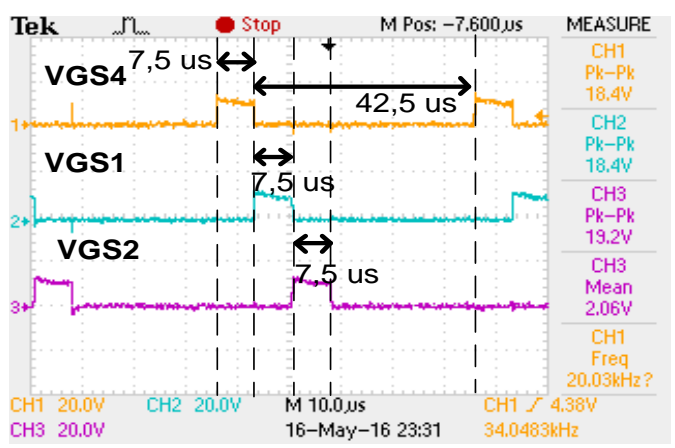

Gambar 11. Gelombang PWM mode1

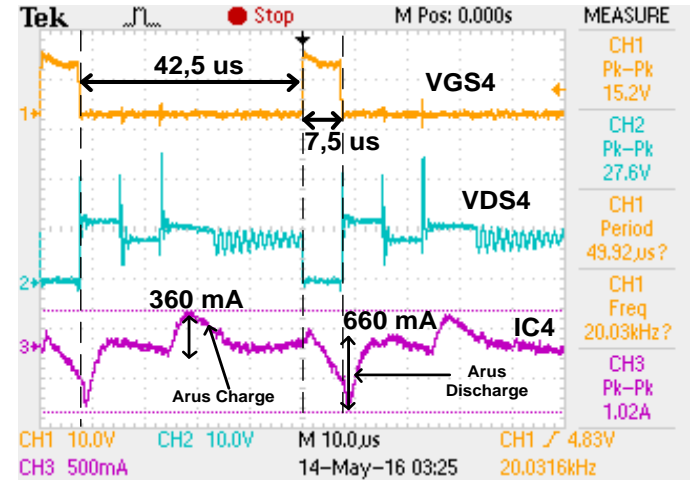

(a)

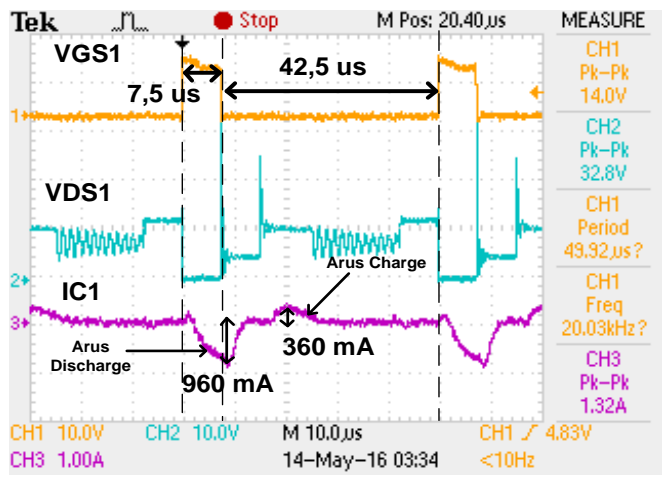

(b)

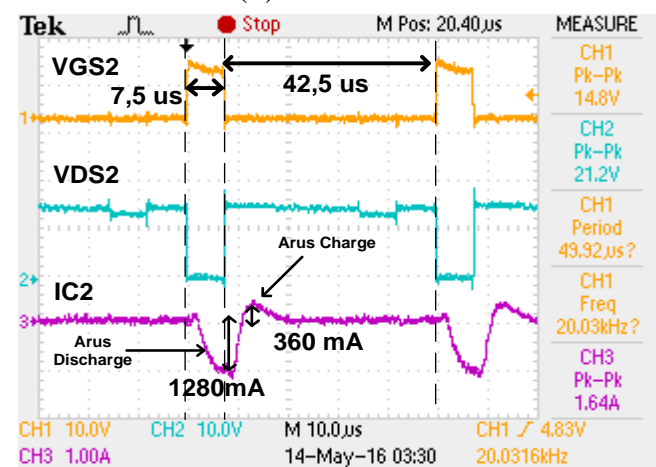

(c)

Gambar 12 Gelombang pensakelaran dan arus (a) $\mathrm{C}_{4}(\mathrm{~b}) \mathrm{C}_{1}(\mathrm{c}) \mathrm{C}_{2}$

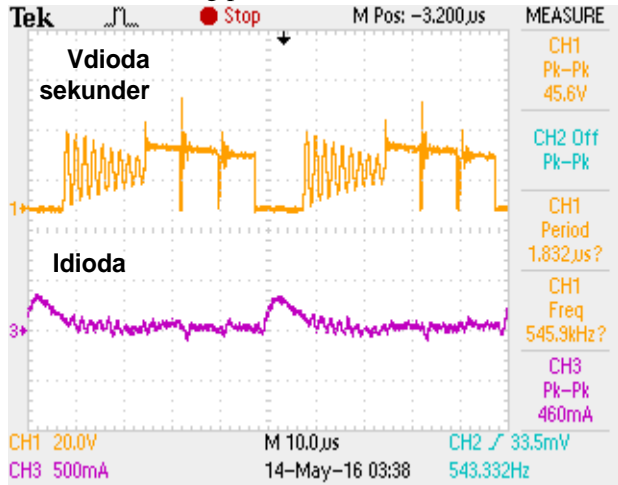

(c)

Gambar 13 Bentuk gelombang tegangan dan arus dioda sekunder

Dari Gambar 11,12, dan 13 menunjukkan bahwa gelombang pensakelaran telah sesuai dengan yang diinginkan. Saat PWM bernilai low maka tegangan sakelar akan bernilai high, begitu juga sebaliknya, saat pergantian pensakelaran 
niali arus akan semakin besar karena sebelum $\mathrm{L}_{\mathrm{m}}$ discharge sakelar selanjutnya ON. saat tidak ada sakelar ON maka akan ada arus charging dari sisi sekunder flyback transformer.

\section{B. Pengujian Ekualisasi Baterai Dengan Tegangan Bervariasi}

Pengujian ini dimaksudkan untuk mengetaui kinerja equalizer saat digunakan untuk menyeimbangkan tegangan sel dengan rentang tegangan yang bervariasi.

\section{a. Case 1}

Case 1 dihadapkan pada tegangan salah satu sel mendekati nilai tertinggi dan tiga sel yang lain memiliki nilai tegangan yang lebih rendah. Nilai tegangan sel $\mathrm{C}_{1}=4,14 \mathrm{~V}, \mathrm{C}_{2}=3,66 \mathrm{~V}$, $\mathrm{C}_{3}=3,67 \mathrm{~V}$, sel $\mathrm{C}_{4}=3,67 \mathrm{~V}$. Setelah proses ekualisasi selama 260 menit keempat tegangan sel menjadi 3,74Volt. Tegangan total awal sebesar $15,14 \mathrm{~V}$ turun 0,16 Volt menjadi $14,96 \mathrm{~V}$. Sebagian besar proses ekualisasi pada case ini equalizer berada pada mode operasi 3. Grafik ekualisasi hasil pengujian ditunjukkan oleh Gambar 14.

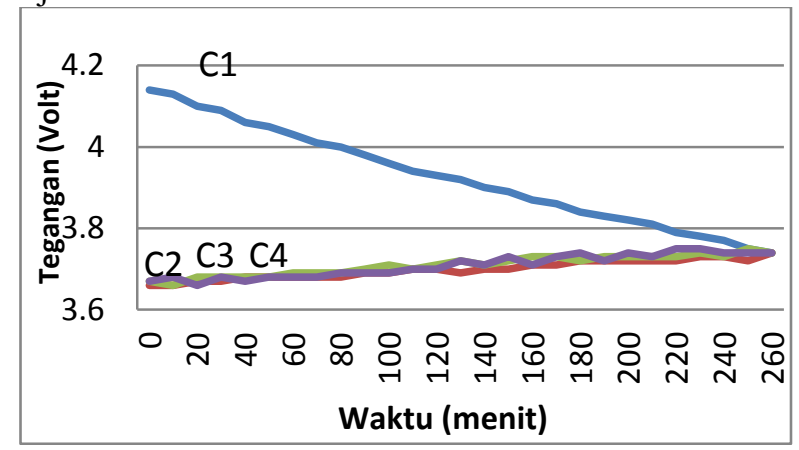

Gambar 14 Grafik ekualisasi case 1

b. Case 2

Case 2 Tegangan 2 sel berada mendekati nilai maksimal dan 2 sel lainnya dengan tegangan yang lebih rendah. Tegangan masing-masing sel adalah: $\mathrm{C}_{1}=4,11 \mathrm{~V}, \mathrm{C}_{2}=4,12 \mathrm{~V}$, $\mathrm{C}_{3}=3,63 \mathrm{~V}, \mathrm{C}_{4}=3,64 \mathrm{~V}$. Waktu yang dibutuhakan untuk proses ekualisasi adalah sebesar 358 menit dengan nilai tegangan akhir sebesar $\mathrm{C}_{1}=3,77 \mathrm{~V}, \mathrm{C}_{2}=3,77 \mathrm{~V}, \mathrm{C}_{3}=3,76 \mathrm{~V}, \mathrm{C}_{4}=3,77 \mathrm{~V}$. Gambar 3.15 merupakan grafik ekualisasi untuk case 2.

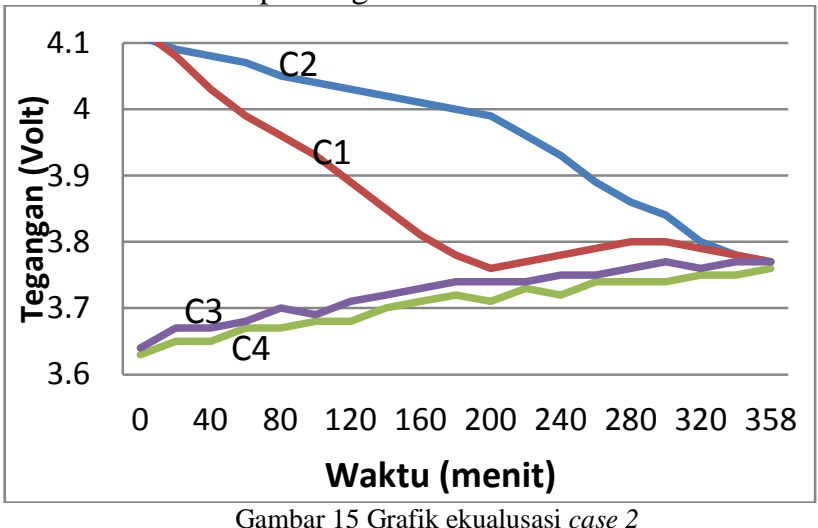

c. Case 3

Pada case 3 tegangan 3 sel baterai dibuat mendekati maksimal dan 1 sel lainnya memiliki tegangan yang lebih rendah. Berikut adalah tegangan untuk masing-masing sel. $\mathrm{C}_{1}=3,64 \mathrm{~V}, \mathrm{C}_{2}=4,09 \mathrm{~V}, \mathrm{C}_{3}=4,1 \mathrm{~V}, \mathrm{C}_{4}=4,14 \mathrm{~V}$. Waktu yang dibutuhakan untuk menyeimbangkan tegangan adalah sebesar 489 menit. Dengan hasil akhir $=3,78 \mathrm{~V}, \mathrm{C}_{2}=3,79 \mathrm{~V}, \mathrm{C}_{3}=3,78 \mathrm{~V}$, $\mathrm{C}_{4}=3,78 \mathrm{~V}$ atau memiliki perbedaan tegangan 0,01 Volt. Gambar 16 merupakan grafik ekualisasi case 3.

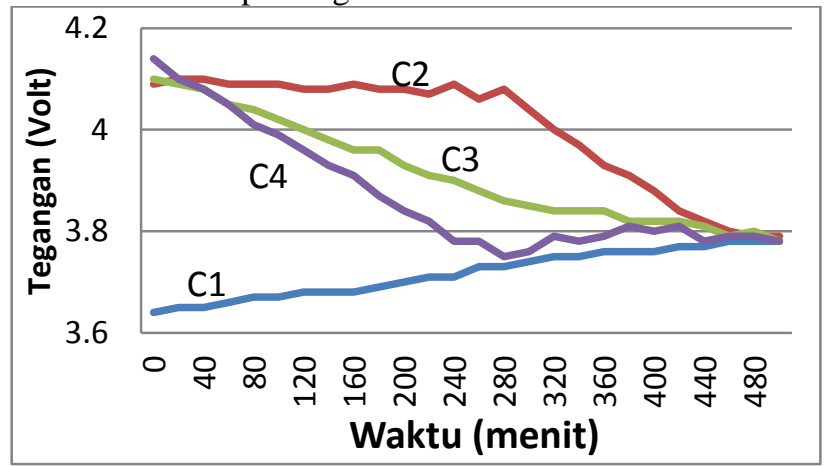

Gambar 16 Grafik ekualisasi Case 3

\section{d. Case 4}

Case 4 tegangan baterai hampir seragam, dengan rentang teritnggi dan terendah sebesar $0,09 \mathrm{~V}$. Berikut adalah tegangan masing-masing sel $=4,06$ Volt, $\mathrm{C}_{2}=4,11 \mathrm{Volt}, \mathrm{C} 3=4,09 \mathrm{Volt}$, $\mathrm{C} 4=4,07$ Volt. waktu yang dibutuhkan untuk menyeimbangkan tegangan sebesar 36 menit dengan hasil akhir tegangan ke empat sel adalah 4,08 Volt. Gambar 17 merupakan grafik ekualisasi case 4 .

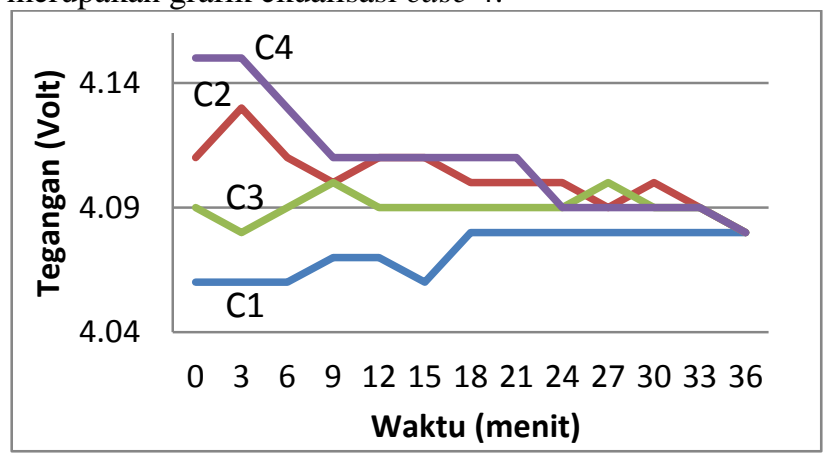

Gambar 17 Grafik ekualisasi case 4

\section{Pengujian Pembebanan Baterai Dengan dan Tanpa Ekualisasi}

Pengujian ini dilakukan untuk mengetahui performa baterai yang telah melalui proses ekualisasi. Baterai akan dikosongkan hingga mencapai tegangan 3 Volt. terdapat 2 perlakuan dalam pengujian ini, pertama 4 sel baterai dengan tegangan masing-masing sel adalah $\mathrm{C}_{1}=3,66 \mathrm{~V}, \mathrm{C}_{2}=3,65 \mathrm{~V}$, $\mathrm{C}_{3}=3,55 \mathrm{~V}$ dan $\mathrm{C}_{4}=3,56 \mathrm{~V}$ dibebani dengan resistor $33 \mathrm{Ohm}$ hingga salah satu sel mencapai tegangan 3 Volt. perlakuan ke dua adalah 4 sel baterai diseimbangkan melalui proses ekualisasi dan di bebani hingga mencapai tegangan 3 volt.

Hasil perlakuan pertama adalah baterai dapat beroperasi selama 42 menit, tepat saat kedua baterai dengan tegangan terendah adalah 3 Volt.

Perlakuan kedua adalah dengan nilai tegangan yang sama perlakuan pertama, keempat sel diseimbangkan tegangannya menggunakan equalizer, lalu dibebani dengan resistor $33 \mathrm{ohm}$. Hasil ekualisasi tegangan pada perlakuan ke dua adalah 
JURNAL TEKNIK ITS Vol. 5, No. 2, (2016) ISSN: 2337-3539 (2301-9271 Print)

$\mathrm{C}_{1}=3,59 \mathrm{~V}, \mathrm{C}_{2}=3,59 \mathrm{~V}, \mathrm{C}_{3}=3,58 \mathrm{~V}, \mathrm{C}_{4}=3,59 \mathrm{~V}$. Hasil pengujian pembebanan menunjukkan waktu operasi mengingkat menjadi 48 menit. Peningkatan waktu operasi sebesar 6 menit dari perlakuan tanpa menggunakan equalizer, atau meningkat sebesar $14 \%$.

\section{KESIMPULAN}

Berdasarkan data hasil simulasi dan pengujian dapat disimpulkan beberapa hasil sebagai berikut:

1. Pengujian bentuk gelombang pada implementasi sudah menyerupai bentuk gelombang simulasi.

2. Lama waktu ekualisasi dipengaruhi oleh besarnya perbedaan tegangan antar sel. Semakin tinggi perbedaan tegangan dengan nilai tegangan sel terendah, waktu ekualisasi semakin lama.

3. Dari hasil pengujian ekualisasi, perbedaan tegangan tiap sel setelah proses ekualisasi maksimal sebesar 0,01 Volt.

4. Peningkatan waktu operasi kerja baterai setelah baterai di ekualisasi adalah sebesar 6 menit, atau 14\% lebih lama dari tanpa perlakuan ekualisasi.

\section{DAFTAR PUSTAKA}

[1] M. Daowd, N. Omar, P. V. Bossche, and J. V. Mierlo, "Passive and active balancing comparison based onMATLAB simulation," in Proc. IEEE Veh.Power Propuls. Conf., Sep. 2011, pp. 1-7.

[2] A. M. Imtiaz, F. H. Khan, and H. Kamath, "Time shared flyback converter" based regenerative cell balancing technique for series connected Li-ion battery strings," IEEE Trans. Power Electron., vol. 28, no. 12, pp. 59605975, Dec. 2013.

[3] Hart, Daniel W.2011."Power Electronics". New York : The McGraw Hill Companies.

[4] Hesterman, Bryce. "Analysis and modeling of Magnetic Cooupling".Denver Chapter, IEEE Power Electronics Socienty. Colorado. 2007 